\title{
Studying the Moderating Effect of a Respondent's Locality in M-commerce Adoption Intention
}

Estudio del efecto moderador en una localidad encuestada sobre la intención de adopción de M-Commerce

\section{Estudo sobre o efeito de moderador da localidade do entrevistado} na intenção de adoção do comércio móvel

\section{Abhishek Tandon ${ }^{1}$ \\ Himanshu Sharma² \\ Anu G. Aggarwal ${ }^{3}$}

Received: May $13^{\text {th }}, 2019$

Accepted: July $27^{\text {th }}, 2019$

Available: September $16^{\text {th }}, 2019$

How to cite this article:

Tandon, H. Sharma, and A.G. Aggarwal, "Studying the Moderating Effect of a

Respondent's Locality in M-commerce Adoption Intention,"

Revista Ingeniería Solidaria, vol. 15, no. 3, 2019.

doi: https://doi.org/10.16925/2357-6014.2019.03.07

Artículo de investigación. https://doi.org/10.16925/2357-6014.2019.03.07

1 Shaheed Sukhdev College of Business Studies, University of Delhi, Delhi, India

ORCID: https://orcid.org/0000-0002-0143-5677

E-mail: abhishektandon@sscbsdu.ac.in

2 Department of Operational Research, University of Delhi, Delhi, India

ORCID: https://orcid.org/0000-0002-1004-9567

E-mail: abhishektandon@sscbsdu.ac.in

3 Department of Operational Research, University of Delhi, Delhi, India

ORCID: https://orcid.org/0000-0001-5448-9540

E-mail: anuagg17@gmail.com 


\section{Abstract}

Introduction: The present research was conducted at the University of Delhi in 2018.

Problem: With the increase in usage of internet technology through wireless devices, the relevance of $\mathrm{m}$-commerce has amplified. In a developing country like India, the rural and urban population is not equally divided on the use of $\mathrm{m}$-commerce and this demands a detailed study regarding this problem.

Objective: The study aims to determine the factors that influence the $\mathrm{m}$-commerce adoption intention of customers and how the effect varies over rural and urban populations.

Methodology: This study combines the TAM and UTAUT model to consider the determinants as perceived ease of use, perceived usefulness, perceived risk, perceived cost, social interaction, and facilitating conditions, taking the endogenous variable as intention to adopt $\mathrm{m}$-commerce.

Results: The results of PLS-SEM accepted the hypotheses underlying the model and also validated the moderating role played by a respondent's locality over the intention to adopt $\mathrm{m}$-commerce.

Conclusion: The proposed model was validated by using PLS-SEM approach on a sample size of 200 collected from the urban and rural areas of Delhi NCR. Moreover, the moderating effect of a respondent's locality was observed over adoption intention.

Originality: With the advancement in technological infrastructure and improvement in mobile data facilities, customers have shown enthusiasm towards making online transactions using their phones. The advantage of mobile commerce over computer based electronic commerce is its mobility. Extant research has shown interest in studying the adoption intention of mobile commerce, based on determinants from the TAM or UTAUT model or their combinations. This study combines both models to choose the determinants of mobile adoption intention.

Limitation: Further studies can be conducted by considering other combinations of determinants and extending the model to incorporate the loyalty measures.

Keywords: mobile commerce; TAM; UTAUT; PLS-SEM; adoption intention; locality.

\section{Resumen}

Introducción: la presente investigación se realizó en la Universidad de Delhi en 2018.

Problema: con el aumento en el uso de la tecnología de Internet a través de dispositivos inalámbricos, la relevancia del comercio móvil se ha ampliado. En un país en desarrollo como India, la población rural y urbana no está dividida por igual en el uso del comercio móvil y esto exige un estudio detallado sobre este problema.

Objetivo: el estudio tiene como objetivo determinar los factores que influyen en la intención de adopción de $\mathrm{M}$-Commerce de los clientes y cómo varía el efecto sobre las poblaciones rurales y urbanas.

Metodología: este estudio combina el modelo TAM y UTAUT para considerar los determinantes como facilidad de uso percibida, utilidad percibida, riesgo percibido, costo percibido, interacción social y condiciones facilitadoras, tomando la variable endógena como intención de adoptar el comercio móvil.

Resultados: Ios resultados de PLS-SEM aceptaron las hipótesis subyacentes al modelo y también validaron el papel moderador desempeñado por la localidad del encuestado sobre la intención de adoptar el comercio móvil.

Conclusión: el modelo propuesto fue validado utilizando el enfoque PLS-SEM en un tamaño de 200 muestras recolectadas de las áreas urbanas y rurales de Delhi NCR. Además, el efecto moderador de la localidad del encuestado se observó sobre la intención de adopción. 
Originalidad: con el avance en la infraestructura tecnológica y la mejora en las instalaciones de datos móviles, los clientes han mostrado entusiasmo por realizar transacciones en línea usando sus teléfonos. La ventaja del comercio móvil sobre el comercio electrónico basado en computadora es su movilidad. La investigación existente ha mostrado interés en estudiar la intención de adopción del comercio móvil, basada en determinantes del modelo TAM o UTAUT o sus combinaciones. Este estudio combina ambos modelos para elegir los determinantes de la intención de adopción móvil.

Limitación: se pueden realizar más estudios considerando otras combinaciones de determinantes y extendiendo el modelo para incorporar las medidas de lealtad.

Palabras clave: comercio móvil, TAM, UTAUT, PLS-SEM, intención de adopción, localidad.

\section{Resumo}

Introdução: a presente pesquisa foi conduzida na Universidade de Delhi em 2018.

Problema: com o aumento do uso da tecnologia da internet através de dispositivos sem fio, a relevância do comércio móvel cresceu. Em um país em desenvolvimento como a Índia, a população rural e urbana não é igualmente dividida no uso de comércio móvel e isso demanda um estudo detalhado com respeito a esse problema.

Objetivo: o objetivo do estudo é determinar os fatores que influenciam a intenção de adesão dos cliente ao comércio móvel e como o efeito varia em populações rurais e urbanas.

Metodologia: o estudo combina o Modelo de Aceitação da Tecnologia (TAM, na sigla em inglês) e o Modelo da Teoria Unificada de Aceitação e Uso da Tecnologia (UTAUT, na sigla em inglês) para considerar os determinantes como facilidade de uso percebida, utilidade percebida, risco percebido, custo percebido, interação social e condições de facilitação, ao considerar variáveis endógenas como intenção de adesão ao comércio móvel.

Resultados: os resultados de Mínimos Quadrados Parciais (PLS-SEM, na sigla em inglês) aceitaram as hipóteses subjacentes ao modelo e também validaram o papel de moderação desempenhado pela localidade de um entrevistado sobre a intenção de adesão ao comércio móvel.

Conclusão: o modelo proposto foi validado com o uso da abordagem de mínimos quadrados parciais (PLSSEM) em um tamanho de amostra de 200 , coletada de áreas urbanas e rurais do Território da Capital Nacional de Delhi. Adicionalmente, o efeito moderador da localidade do entrevistado foi observado na intenção de adesão.

Originalidade: com o avanço da infraestrutura tecnológica e a melhora nos equipamentos de dados móveis, os clientes mostraram entusiasmo com respeito à realização de transações on-line pelo telefone. A vantagem do comércio móvel sobre o comércio eletrônico baseado no computador é a mobilidade. Pesquisas prévias mostraram interesse em estudar a intenção de adoção do comércio móvel, com base em determinantes dos modelos TAM ou UTAUT e suas combinações. Este estudo combina ambos os modelos para escolher os determinantes da intenção de adoção móvel.

Limitação: estudos futuros podem ser conduzidos ao considerar outras combinações de determinantes e estender o modelo para incorporar as medidas de fidelidade.

Palavras-chave: comércio móvel; TAM; UTAUT; PLS-SEM; intenção de adesão; localidade.

\section{INTRODUCTION}

Over the past two decades, improvements in information and communication technology have led to a shift from electronic commerce (e-commerce) towards mobile commerce (m-commerce). M-commerce may be defined as "buying and selling 
products/services through a wireless device such as cellular phone" [1, 2]. The establishment of various smartphone brands has promised an increase in the intention to adopt m-commerce, using these wireless devices, among the Indian population. As per the reports presented in 2015, the smartphone users were growing at a rate of $23 \%$, reaching the mark of 220 million. It is expected that by 2020 , India will be the second largest market for smartphones, after China [3]. According to the statistics reported by them, mobile commerce is expected to rise at a rate of $50-55 \%$ in 2018 as compared to the year on year rate of $35 \%$ in 2017. As per a report by ASSOCHAM, demonetization and reduction in cash transactions, along with improvements in net banking facilities, promise a wider scope for mobile commerce [4].

The use of mobile commerce has shifted towards the rural Indian population, where the penetration rate is a meager $18 \%$. Last year, mobile internet users showed an increasing rate of over 15\%, with most of the users (57\%) below the age of 25 [5]. As per the Internet and Mobile Association of India (IMAI), with a penetration rate of $59 \%$, the urban Indian areas are showing a decreasing trend. The number of overall mobile internet users are expected to reach 478 million by 2020, out of which 291 million will be urban users whereas 187 million will be from rural areas. There has been a tremendous increase of $17.2 \%$ from December 2016 to 2017, reaching a number of 456 million [6]. This increase is complimented by new forms of applications and quality of mobile data. Their report highlights a sharp decline in the number of respondents reporting online finance and transactions across both urban and rural India, implying that digital transactions are yet to attain priority for mobile internet usage. However, online financial transactions have witnessed a rise compared to previous years and are one of the most promising of services for mobile internet in the near future.

Therein lies the motivation to propose a research article that combines the theoretical view of the technology adoption process and also provide discussions that support this difference in adoption by rural and urban areas; especially in a developing country like India. This paper combines the technology acceptance model (TAM) and unified theory of adoption and use of technology (UTAUT) model to judge the factors that influence the mobile commerce adoption intention and to check the role of these factors under the influence of locality of the respondent. A structural framework is proposed with the 'intention to adopt $\mathrm{m}$-commerce' taken as an endogenous latent variable and considering various exogenous variables namely: perceived ease of use (PEOU), perceived usefulness (PU), perceived risk (PR), perceived cost (PC), social influence (SI), and facilitating conditions (FC). The framework is solved through partial least squares - structural equation modeling (PLS-SEM) approach. PLS is an extension of the covariance based structural equation modeling (CBSEM) approach, a soft 
modeling technique without any distributional assumption on the data with some major improvements [7]. PLS emphasizes on providing the maximum explained variance of the endogenous latent variables by estimating the parameters of the model using the ordinary least squares (OLS) method [8].

To validate the proposed model, a sample of 200 respondents was collected through convenience sampling, with 100 sample units in each locality i.e. urban and semi urban (rural) areas of the Delhi NCR region. The data obtained was processed to obtain the PLS-SEM path modeling results and the moderating effect was checked using the smartPLS 2.0 software. The remaining structure of this paper is as follows: Section 2 highlights the literature review with respect to the TAM and UTAUT model, hypotheses are developed in Section 3, Section 4 gives a glimpse of the methodology for the proposed model, data analysis is performed in Section 5, lastly Section 6 focuses on the discussions and the conclusion based on the study.

\section{LITERATURE REVIEW}

\subsection{Technology Acceptance Model (TAM)}

Over the past few decades, many prominent theories have been proposed by researchers that predict the intention of a customer to accept the information systems (IS). The acceptance of these IS determinants leads to the success of an e-firm [2]. One of the models that has gained popularity over the years is the technology acceptance model (TAM), restructured from the theory of reasoned action (TRA), developed by Davis [9]. According to the TAM, the intention of an individual to accept a piece of technology is influenced majorly by two key factors: perceived ease-of-use (PEOU) and perceived usefulness (PU). PEOU means "the degree to which IS would be easy to handle", whereas PU refers to the "degree by which using a technology will enhance the job performance of an individual" [10]. Past studies have replicated the TAM in three ways. (1) Some studies focused on gaining insights into the psychometric features of TAM constructs; (2) A few concentrated on the theories underlying the TAM indicators PEOU and PU; and (3) Major contributions by researchers have aimed to extent the model to add a few more determinants according to their objectives for the study [11]. Later, TAM2 was introduced that included more determinants of the intention to use a technology by an individual [12]. The model was updated by adding the concepts of social influence and cognitive instruments, which helped in defining PU and adoption purposes. Social influence included the subjective norms and image [13]. Subjective norm is defined as the "degree to which the people around the potential adopter think 
that he should adopt or ignore the technology". Image depicts the "perception of an individual that the use of the technology will increase their status in society" [14]. On the other hand, cognitive instruments incorporate four variables; namely job relevance, output quality, PEOU, and result demonstrability. Job relevance means the applicability of the system to its prescribed work. Output quality represents the ability of the system to perform the stated tasks well. Result demonstrability depicts the degree to which the outputs obtained through a system are tangible, observable, and communicable [15]. Even though TAM was considered to be a robust and powerful method to judge user acceptance, some academicians still emphasized on expanding the model by inculcating a few constructs $[16,17]$.

\subsection{Unified Theory of Adoption and Use of Technology (UTAUT)}

The studies related to the acceptance of technology by the end user have shown progression over the years. This has led to the emergence of various behavioral models, the latest being UTAUT. This model is an upgrade of the TAM and is considered to be more robust than the former [18]. It is a novel method based upon social cognitive theory and is an amalgamation of eight user acceptance models such as: TRA, theory of planned behavior (TPB), TAM, motivational model (MM), combination of TAM and TPB, model of PC utilization, innovation diffusion theory, and socio cognitive theory. The model consists of four determinants of usage and intention namely: performance expectancy, effort expectancy, social influence, and facilitating conditions [13]. Performance expectancy refers to the ability of the technology to provide profits to the customers while performing their activities. Effort expectancy represents the degree of ease the customers face while using the technology for their tasks. Facilitating conditions are defined as the "resources and support availability to facilitate a customer's behavior". Social influence means the importance attached towards the peers and family in making a decision.Venkatesh, et al. [19] developed the UTAUT2 model, an extension of the UTAUT model. Under this model, they included a few additional determinants; namely habit, hedonic motivation, and price value. Habit is defined as the ability of the customer to perform activities automatically after having learnt to use the technology. Hedonic motivation relates to the enjoyment and motivation experienced while making use of the technology. Price value conquers the price-value tradeoff faced by the user of the technology.

Use of the aforementioned models has been made in recent literature either by considering the model alone or their combinations. This trend is especially true for the scholars working in the field of mobile commerce. Extant researchers have 
shown interest in finding the determinants of the adoption of mobile commerce and its behavioral usage intention. A comprehensive list of the studies performed using TAM, UTAUT, or their combination, in the past few years is provided in Table 1.

Table 1. List of Previous Research.

\begin{tabular}{|c|c|c|c|}
\hline Determinants & Author(s) & Research Objective & $\begin{array}{l}\text { Analysis } \\
\text { Technique }\end{array}$ \\
\hline $\begin{array}{l}\text { Trust and privacy, utility expectancy, effort ex- } \\
\text { pectancy, social factors, convenience and cost. }\end{array}$ & {$[17]$} & $\begin{array}{l}\text { Mobile commerce user } \\
\text { acceptance study in } \\
\text { China. }\end{array}$ & Theoretical \\
\hline $\begin{array}{l}\text { PU, PEOU, social influence, perceived security, } \\
\text { trust, self efficacy. }\end{array}$ & {$[20]$} & $\begin{array}{l}\text { Consumer acceptance } \\
\text { of mobile payments. }\end{array}$ & $\begin{array}{l}\text { Structural equation } \\
\text { modeling (SEM) }\end{array}$ \\
\hline $\begin{array}{l}\text { Perceived convenience, perceived benefit, trust, } \\
\text { perceived risk, social norm, computer efficacy. }\end{array}$ & {$[21]$} & $\begin{array}{l}\text { Consumer acceptance } \\
\text { of mobile payments. }\end{array}$ & SEM \\
\hline $\begin{array}{l}\text { Performance expectancy, effort expectancy, so- } \\
\text { cial influences, facilitating conditions, perceived } \\
\text { enjoyment, attention focus. }\end{array}$ & {$[22]$} & $\begin{array}{l}\text { Mobile internet conti- } \\
\text { nuance usage }\end{array}$ & SEM \\
\hline $\begin{array}{l}\text { Performance expectancy, effort expectancy, so- } \\
\text { cial influences, facilitating conditions, perceived } \\
\text { credibility, perceived self efficacy, perceived } \\
\text { financial cost. }\end{array}$ & {$[23]$} & Mobile banking usage & $\begin{array}{l}\text { Partial least squares } \\
(\mathrm{PLS})\end{array}$ \\
\hline $\begin{array}{l}\text { Performance expectancy, effort expectancy, } \\
\text { social influences, facilitating conditions. }\end{array}$ & {$[24]$} & $\begin{array}{l}\text { Mobile payment } \\
\text { services adoption by } \\
\text { professionals. }\end{array}$ & Multiple regression \\
\hline PU, PEOU, relationship, playfulness. & {$[10]$} & $\begin{array}{l}\text { Smartphone user adop- } \\
\text { tion in Korea. }\end{array}$ & PLS-SEM \\
\hline $\begin{array}{l}\text { Performance expectancy, effort expectancy, so- } \\
\text { cial influences, innovativeness, trust in system, } \\
\text { perceived risk. }\end{array}$ & {$[25]$} & $\begin{array}{l}\text { Mobile payments adop- } \\
\text { tion in UK. }\end{array}$ & SEM \\
\hline $\begin{array}{l}\text { Performance expectancy, effort expectancy, } \\
\text { social influences, perceived risk, perceived cost. }\end{array}$ & {$[16]$} & $\begin{array}{l}\text { Mobile payment adop- } \\
\text { tion intention. }\end{array}$ & SEM \\
\hline $\begin{array}{l}\text { Self efficacy, social influence, performance risk, } \\
\text { privacy risk, utilitarian performance expectancy, } \\
\text { hedonic performance expectancy, effort expec- } \\
\text { tancy, trust, facilitating conditions, security. }\end{array}$ & {$[26]$} & $\begin{array}{l}\text { NFC based mobile pay- } \\
\text { ments in the restaurant } \\
\text { industry. }\end{array}$ & PLS-SEM \\
\hline $\begin{array}{l}\text { Performance expectancy, effort expectancy, } \\
\text { perceived risk. }\end{array}$ & {$[27]$} & $\begin{array}{l}\text { Mobile banking adop- } \\
\text { tion in Pakistan. }\end{array}$ & PLS-SEM \\
\hline
\end{tabular}

Source: own work

\section{HYPOTHESIS DEVELOPMENT}

\subsection{Intention to Adopt Mobile Commerce}

Behavioral intention is defined as "a measure of the strength of one's intention to perform a specified behavior". The most breakthrough research was the TAM which 
modeled the adoption of IT/IS systems by the customers and gained insights into the determinants that drive their intention; both positively and negatively [28]. Even though they were able to model the acceptance and adoption of the technologies, there still existed a need to incorporate a few customer specific changes according to their domains of interest [16]. Thus, researchers tried to extend the TAM to incorporate their domain specific constructs in order to validate the behavioral intention with respect to newer technologies [29]. With changing technology, the computer-based, traditional adoption studies are fading over time and making way for new technologies consisting of mobile commerce, with specifications such as location specificity, ubiquity, time independence, and personalized services [30]. This forced the extension of the TAM to UTAUT and a combination of these concepts was able to elucidate the adoption behavior of customers towards m-commerce [14]. This paper aims to study the adoption intention of customers towards m-commerce by combining key characteristics of the TAM and UTAUT model and also discusses the effect of locality on the adoption pattern.

\section{Perceived Ease of Use (PEOU)}

PEOU is defined as the "degree to which a person believes that using a particular system would be free of effort". It is one of the determinants in the TAM and it was assumed that PEOU indirectly influenced the usage intention via PU [9]. However, decades of work proved that there exists both a direct effect and an indirect effect through PU [10]. Mobile commerce faces some problems, due to small screen size and inconvenient output, in comparison to electronic commerce which makes use of computers. If the firm is not able to provide the customers with an application with a good interface and ease in performing transactions, it may hamper his continuous usage intention [20]. An ease-of-use m-commerce application will reduce the effort of the end user and hence result in a favorable attitude towards its adoption. We posit that,

H1: PEOU has a significant positive effect on the intention to adopt mobile commerce.

\section{Perceived Usefulness (PU)}

PU refers to the "degree to which a person believes that using a particular system will enhance his or her job performance". PU is believed to be an antecedent for satisfaction by many IS studies [9]. As per the research done in the field of internet, information systems, web, and mobile commerce, PU is considered to be an important predictor 
of end user acceptance intention. Previous researchers have shown the positive impact of PU over a user's satisfaction and usage continuance behavior [10]. PU may be indeterminate to the confirmation experience of the user, mainly due to the fuzziness in their expectations from the IS [15]. Hence, we posit that,

$\mathrm{H}$ 2: PU has a significant positive effect on intention to adopt mobile commerce.

\section{Perceived Risk}

Perceived risk refers to "certain types of financial, product performance, social, psychological, physical, or time risks when consumers make transactions online" [25]. With the popularity of the internet, customers are keen on finding the different types of risks pertaining to the system while making an online transaction. Another type of risk encountered by the end user is the product quality, product delivery issues, making a transaction without receiving a product/service, and other fraudulent activities and frauds available online [26]. Perceived risk, which is deemed to be a determinant of a customer's attitude towards online payment processes, is highly vulnerable to various cognitive and affective factors. Since adoption decision involves some uncertainty on the part of users, it is therefore believed that perceived risk acts as a predecessor of behavioral intention [21]. Thus, we posit that,

H3: Perceived Risk has a significant negative effect on intention to adopt mobile commerce.

\section{Perceived Cost}

Perceived cost is defined as "the costs involved in making use of a mobile commerce application". Even though customers face negligible costs in switching between products and brands, some additional expenses are still incurred when making a transition from the wire-mode to wireless-mode [23]. Three distinguishing expenses incorporated while using a mobile commerce are: access cost, equipment cost, and transaction cost. Moreover, users have to pay for unavoidable situations such as slow connection, poor quality, non accurate content, and errors while performing some activities [17]. The mobile commerce providers must work on providing an efficient and effective application which will enhance the experience of the end user and this will lead to long term commitments and profit for firms. Thus, cost is considered to be an important determinant for mobile commerce to thrive as many alternative solutions are available to the customers [31]. Therefore, we posit that, 
H4: Perceived Cost has a significant negative effect on intention to adopt mobile commerce.

\section{Social Influence}

Social influence refers to the "extent to which consumers perceive that important others (e.g. family and friends) believe they should use a particular piece of technology" [19]. Previous researchers have distinguished between two types of social influence: mass media influence and interpersonal influence. Under the mass media influence, we consider instruments such as newspapers, internet, radio, television, magazines, etc. Whereas, interpersonal influence incorporates the people belonging to our society such as peers, family, superiors, etc. [13]. It is believed that mobile commerce users are inclined by family, friends, media, and other users in their intention to adopt the technology. People are affected by the behavior of other mobile service users in the public and hence there is a possibility of social influence impacting the behavioral intention [25]. Therefore, we assert that,

H5: Social Influence has a significant positive effect on intention to adopt mobile commerce.

\section{Facilitating Conditions}

A facilitating condition is defined as the "consumers' perceptions of the resources and support available to perform a behavior" [19]. It is assumed that new technology adopters are always looking for help from experienced people having used the technology before [26]. According to them, absence of facilitating conditions may hamper the behavioral intention of the potential user. It is observed that the use of mobile commerce prospers in the presence of knowledgeable people who are ready to help those lacking technological essence [24]. Facilitating conditions are mainly composed of online help and support, internet connections, and many more. Therefore, we state that,

H6: Facilitating conditions have a significant positive effect on intention to adopt mobile commerce.

\subsection{Moderating Effect of Locality}

The path analysis related studies mainly considering two effects that impact the direction and magnitude of the relationship between the latent variables; namely 
moderating effect and mediating effect. The moderating effect talks about how an additional variable enhances or decreases the relationship between the constructs, whereas the mediating effect emphasizes a key construct, without which a relationship is not defined or significant [32]. Though some studies exist that concentrate on the moderating effects of age, demographic factors, trust, gender, and many more on $\mathrm{m}$-commerce adoption intention, keeping the TAM or UTAUT model or their combination framework in background [33], they have ignored the impact of locality. This is a unique study that considers the impact of urban and rural population on m-commerce adoption intention, which to the best of our knowledge has not been previously considered. Therefore we posit that,

$\mathrm{H7}$ : The effect of PEOU on a user's intention to adopt is moderated by locality.

H8: The effect of PU on a user's intention to adopt is moderated by locality.

H9: The effect of Perceived Risk on a user's intention to adopt is moderated by locality.

H10: The effect of Perceived Cost on a user's intention to adopt is moderated by locality.

H11: The effect of Social Influence on a user's intention to adopt is moderated by locality.

H12: The effect of Facilitating Conditions on a user's intention to adopt is moderated by locality.

\section{METHODOLOGY}

\subsection{Study Participants}

The sampling frame consisted of 200 people residing in the urban and semi-urban (rural) areas of Delhi-NCR in India. The sampling unit consisted of only those who made a transaction through their mobile phone (true representative population) in the past few months. Out of the total 200 respondents, $62 \%$ were male, with the majority of them i.e. $55 \%$ belonging to the age group of 18-30 years. Moreover, most of them were graduates (52.5\%) or post-graduates (25\%); belonged to the category of student (30\%) or worked in private organizations (25\%); and earned annually 3-6 Ipa (55\%). The basic characteristics of the survey respondents are provided in Table 2. 


\subsection{Data Collection}

Since the motive is to verify the impact of locality on m-commerce adoption, a convenience sampling technique (a form of non-probability sampling technique) was adopted. The respondents were questioned individually by the interviewer, and explanations were provided for questions which were difficult to comprehend. Also, after filtering, the sampling unit consisted of only those who make transactions through their mobile phone (true representative population), which summed up to 200. To maintain homogeneity in the results, both populations contributed the same number of samples. The sampling time was from the $1^{\text {st }}$ of April 2018 to the $1^{\text {st }}$ of July 2018.

\subsection{Measurement}

Here, we propose a model to find the determinants of mobile commerce adoption along with the moderating effect of locality. The model combines the indicator variables suggested in the TAM and UTAUT model namely PEOU, PU, PC, PR, FC, and SI, while checking their association (negative or positive) with the behavioral intention to adopt mobile commerce. The objective will be fulfilled by checking the validation of the hypotheses suggested in the previous section, and providing further comments on the moderating effect using the technique of PLS-SEM. A prototype of the hypothesized model is shown in Figure 1. To administer these hypotheses, a structured questionnaire was used to get the responses based on twenty constructs. The respondents were questioned about locality, PEOU in using MC (three items, 5-point likert scale), PU of MC (three items, 5-point likert scale), PR in using MC (three items, 5-point likert scale), PC in using MC (three items, 5-point likert scale), SI of MC (three items, 5-point likert scale), FC for MC (three items, 5-point likert scale), and the intention to adopt m-commerce (two items, 5-point likert scale). The statements of the constructs are provided in the appendix. 


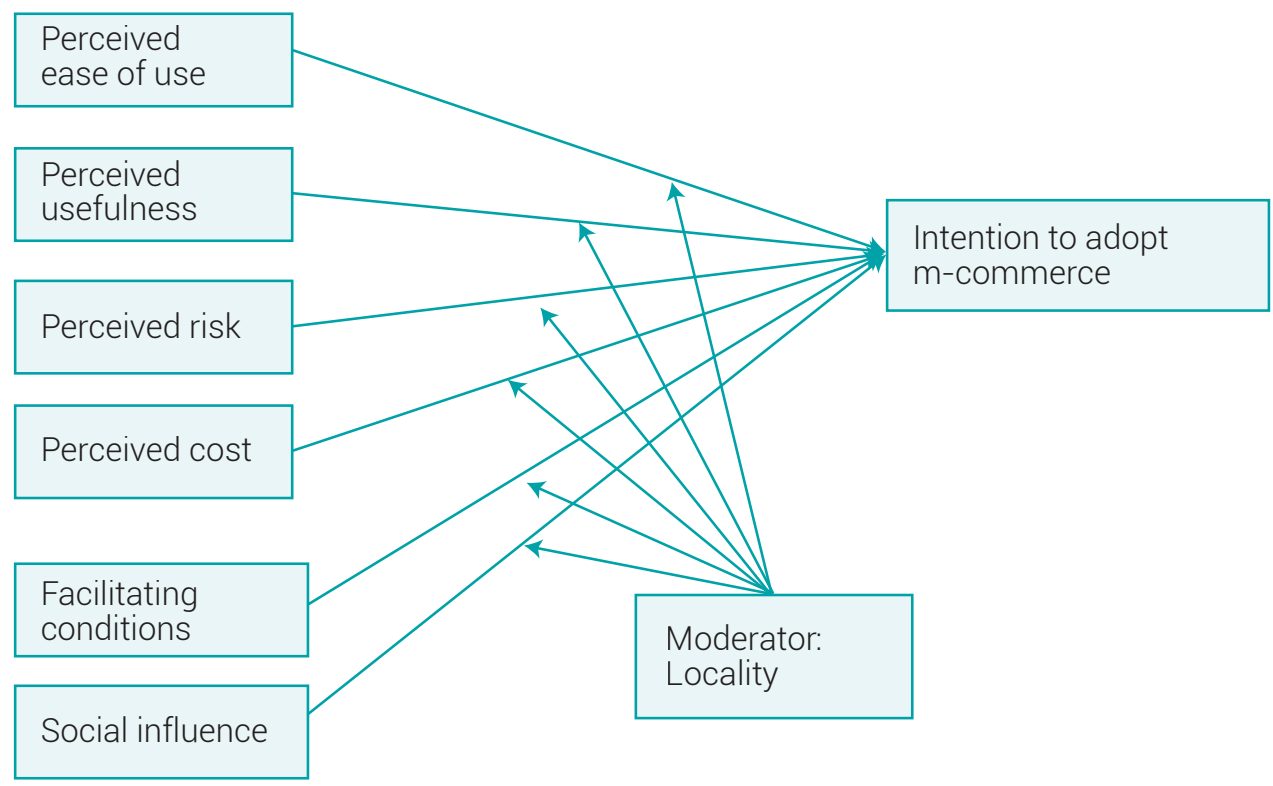

Figure 1. Hypothesized Model. Source: own work

Table 2. Demographic Results.

\begin{tabular}{|c|c|c|c|}
\hline Demographic Factors & Items & Usable Responses & Percentage (\%) \\
\hline \multirow[t]{2}{*}{ Gender } & Male & 124 & 62 \\
\hline & Female & 76 & 38 \\
\hline \multirow[t]{4}{*}{ Age } & Below 18 & 6 & 3 \\
\hline & $18-30$ & 110 & 55 \\
\hline & $31-45$ & 60 & 30 \\
\hline & Above 45 & 24 & 12 \\
\hline \multirow[t]{2}{*}{ Locality } & Urban & 100 & 50 \\
\hline & Semi-urban (Rural) & 100 & 50 \\
\hline \multirow[t]{5}{*}{ Educational Qualification } & Highschool or less & 10 & 5 \\
\hline & Secondary & 15 & 7.5 \\
\hline & Senior secondary & 20 & 10 \\
\hline & Graduate & 105 & 52.5 \\
\hline & Post-graduate & 50 & 25 \\
\hline \multirow[t]{5}{*}{ Occupation } & Unemployed & 20 & 10 \\
\hline & Student & 60 & 30 \\
\hline & Government job & 30 & 15 \\
\hline & Private job & 50 & 25 \\
\hline & Business/Own work & 40 & 20 \\
\hline
\end{tabular}




\begin{tabular}{cccc}
\hline Demographic Factors & Items & Usable Responses & Percentage (\%) \\
\hline Annual household income (in Ipa) & Less than 3 & 10 & 5 \\
\cline { 2 - 4 } & $3-6$ & 110 & 55 \\
\cline { 2 - 4 } & Above 6 & 80 & 40 \\
\hline
\end{tabular}

Source: own work

\section{DATA ANALYSIS}

\subsection{Validity and Reliability of Measures}

Exploratory factor analysis (EFA) was performed for scale rectification of measures. The principal component analysis (PCA) with varimax rotation and eigenvalues greater than one were considered and items with loadings higher than 0.5 were retained for the analysis. A Kaiser-Mayer-Olkin (KMO) value of 0.687 and significant Bartlett's Sphericity Test suggest the validation of using factor analysis. Each of the seven constructs considered had Cronbach alpha values greater than 0.7 and composite reliability values above 0.6 , which confirmed construct reliability. Confirmation of discriminant validity of the constructs were observed with average variance extracted (AVE) values above 0.4 and the square root of AVE for each construct is more than the absolute correlations between these latent variables. Table 3 and 4 represent the aforementioned results.

Table 3. Dimensionality and Reliability Results.

\begin{tabular}{lcccc}
\hline \multicolumn{1}{c}{ Variable } & Items & Loadings & Cronbach Alpha & CR \\
\hline \multirow{2}{*}{ Perceived Ease of Use (PEOU) } & PEOU1 & 0.687 & 0.707 & \multirow{2}{*}{0.78} \\
\cline { 2 - 4 } & PEOU2 & 0.788 & 0.707 & \multirow{2}{*}{0.83} \\
\cline { 2 - 4 } Perceived Usefulness (PU) & PEOU3 & 0.739 & 0.795 \\
\cline { 2 - 4 } & PU1 & 0.856 & 0.796 & \multirow{2}{*}{0.68} \\
\cline { 2 - 4 } & PU2 & 0.869 & 0.788 & 0.700 \\
\cline { 2 - 4 } Perceived Risk (PR) & PU3 & 0.613 & 0.713 & \\
\cline { 2 - 4 } & PR1 & 0.552 & 0.717 & 0.788 \\
\hline
\end{tabular}

(continúa) 
(viene)

\begin{tabular}{|c|c|c|c|c|}
\hline Variable & Items & Loadings & Cronbach Alpha & CR \\
\hline \multirow{3}{*}{ Perceived Cost (PC) } & $\mathrm{PC} 1$ & 0.708 & 0.701 & \multirow{3}{*}{0.75} \\
\hline & PC2 & 0.694 & 0.705 & \\
\hline & PC3 & 0.713 & 0.797 & \\
\hline \multirow{3}{*}{ Social Influence (SI) } & SI1 & 0.824 & 0.717 & \multirow{3}{*}{0.88} \\
\hline & $\mathrm{SI} 2$ & 0.872 & 0.729 & \\
\hline & $\mathrm{SI} 3$ & 0.814 & 0.738 & \\
\hline \multirow{3}{*}{ Facilitating Conditions (FC) } & $\mathrm{FCl}$ & 0.803 & 0.732 & \multirow{3}{*}{0.87} \\
\hline & FC2 & 0.786 & 0.725 & \\
\hline & FC3 & 0.886 & 0.712 & \\
\hline \multirow{2}{*}{ Intention to adopt m-commerce (IA) } & $\mid \mathrm{A} 1$ & 0.829 & 0.742 & \multirow{2}{*}{0.8} \\
\hline & IA2 & 0.805 & 0.747 & \\
\hline
\end{tabular}

Source: own work

Table 4. Discriminant Validity Results.

\begin{tabular}{ccccccccc}
\hline & AVE & PU & FC & SI & PEOU & PC & PR & IA \\
\hline PU & $\mathbf{0 . 6 2}$ & $\mathbf{0 . 7 9}$ & & & & & & \\
\hline FC & $\mathbf{0 . 6 8}$ & 0.33 & $\mathbf{0 . 8 2}$ & & & & & \\
\hline SI & $\mathbf{0 . 7 0}$ & 0.32 & 0.12 & $\mathbf{0 . 8 4}$ & & & & \\
\hline PEOU & $\mathbf{0 . 5 5}$ & 0.37 & 0.39 & 0.20 & $\mathbf{0 . 7 4}$ & & & \\
\hline PC & $\mathbf{0 . 5 0}$ & 0.38 & 0.26 & 0.23 & 0.41 & $\mathbf{0 . 7 1}$ & & \\
\hline PR & $\mathbf{0 . 4 2}$ & 0.09 & 0.06 & 0.01 & 0.06 & 0.16 & $\mathbf{0 . 6 5}$ & \\
\hline IA & $\mathbf{0 . 6 7}$ & 0.34 & 0.32 & 0.42 & 0.41 & 0.15 & 0.12 & $\mathbf{0 . 8 2}$ \\
\hline
\end{tabular}

Source: own work

\subsection{Common Method Bias (CMB)}

Using the same survey instrument to get inputs for independent and dependent entities, results in the problem of CMB. This can be detected through Harman's Single Factor Analysis method. In this study, we observe that it is free from CMB as a single factor is able to explain only $39.81 \%$ of the total variance explained.

\subsection{PLS-SEM Results}

The most important prerequisite for a structural model assessment is the evaluation of the quality of the structural model. This can be judged on the basis of the ability 
of the model to be able to predict the endogenous latent variables. This can be measured with the help of coefficient of determination $\left(R^{2}\right)$, cross validated redundancy $\left(Q^{2}\right)$, the effect size $f^{2}$, and path coefficients.

The $R^{2}$ is an in-sample, predictive accuracy measure based on the amount of variance explained by the endogenous variables. From the structural model results we observe that the coefficient of determination value is 0.347 , which is deemed to be of moderate accuracy. Another method for predictive relevance is $Q^{2}$, obtained through the blindfolding procedure available in smartPLS software. After estimating the parameters of the model, it predicts the omitted variables with the help of previously generated results in accordance with these parameters. The smaller the the gap between the predicted and actual parameter values, the larger the instrument's value and the greater the predictive accuracy of that endogenous latent variable in the model. As communicated by previous researchers, a value above zero is an acceptable threshold [34]. The values can be obtained through two approaches. The first approach relies on cross validated redundancy whereas the second depends on cross validated communality. However, the values based on redundancies are preferred in extant studies [35]. Here, the endogenous variable, i.e. intention to adopt $m$-commerce, has a $Q^{2}$ value of 0.2 . The values were obtained after running the blindfolding method with an omission distance of seven.

In addition, we find the values of the effect size, i.e. $f^{2}$, which determines the effect of a predictor construct on an endogenous latent construct. In this paper, we calculated the effect size for website service quality, support, personalization and EWOM, which were found to be within the range of medium-small, with the outcomes numbering $0.06,0.03,0.03,0.04,0.05$, and 0.04 , respectively. The hypothesized relationships between e-commerce success and its success factors were examined through PLS-SEM using smartPLS (2.0) software to determine the path loadings between each pair of latent variables, the coefficient of determination value for the endogenous latent variable, and lastly the t-value to test the significance of the assumptions. The coefficient of determination value was found to be 0.347 and a bootstrapping technique was used to obtain the t-test values, which were greater than the threshold value of 1.96 for acceptance. The hypothesis testing results are shown in Table 6. 
Table 6. Hypothesis Testing Results.

\begin{tabular}{cccc}
\hline Hypothesis & Path Loadings & t-test Values & Status \\
\hline H1 & 0.284 & 7.822 & Supported \\
\hline H2 & 0.147 & 4.253 & Supported \\
\hline H3 & -0.123 & 2.730 & Supported \\
\hline H4 & -0.156 & 3.953 & Supported \\
\hline H5 & 0.331 & 9.877 & Supported \\
\hline H6 & 0.159 & 4.737 & Supported \\
\hline
\end{tabular}

Source: own work

Moreover, a check was made for the moderating effect of locality over the mobile commerce adoption intention. In literature, two types of variables are considered for the purpose of moderation; namely continuous and categorical. Since we want to study the impact of urban and rural populations on the endogenous construct, we considered the categorical method. Using the formulae mentioned by Gaskin [36], we tested the hypotheses using t-statistic values. The results of the moderation-underlined hypotheses are provided in Table 7.

Table 7. Moderation Results.

\begin{tabular}{ccc}
\hline Hypothesis & t-test Values & Status \\
\hline$H 7$ & 4.323 & Supported \\
\hline$H 8$ & 3.896 & Supported \\
\hline$H 9$ & 2.211 & Supported \\
\hline$H 10$ & 2.579 & Supported \\
\hline$H 11$ & 5.135 & Supported \\
\hline$H 12$ & 4.012 & Supported \\
\hline
\end{tabular}

Source: own work

\section{DISCUSSIONS AND CONCLUSION}

From the PLS-SEM results provided in Table 6, we observe that all the hypotheses were supported. Also, Table 7 shows the agreement of the moderation of locality along with the exogenous variables in accomplishing the objective of behavioral intention. The support for Hypothesis 7 suggests that the respondent's locality is influenced by perceived easiness in using the new technology in adopting mobile commerce. The basic 
difference lies in the aptitude and activeness in adapting to changing technology between the people living in rural and urban areas. Therefore, firms should concentrate on building applications that are easy to handle and provide smooth transactions. Since people look out for the advantages within a system post usage, this is validated by the acceptance of Hypothesis 8.

Though people in different areas have different expectations from the technology they are willing to use, their thinking can be generalized in that it should make tasks simple and quick. The transaction process highly impacts the adoption pattern. Even though the urban respondents have more knowledge about the $\mathrm{m}$-commerce system in comparison to rural people, in the case of security and privacy issues relate to an online transfer of money towards the payment for a product/service, they are on the same page. This proves the status of Hypothesis 9. The same goes with perceived cost, as provided by accepting Hypothesis 10. The investment in adopting and continued usage of the mobile technology affects the respondent's acceptance intention. Although with many smartphone brands coming up and advancements in technological infrastructure, firms are trying to achieve this cost-value tradeoff; but it still needs to be simplified to a greater extent. High income makes it possible for urban population to have access to the latest gadgets and facilities attached to it whereas the rural population lacks such luxury.

The support for Hypothesis 11 shows the importance of social communications over adoption intention. Urban respondents are majorly involved in online communication in the form of providing reviews related to the products/services and mobile commerce applications directly over their page or over social media websites. On the other hand, rural people are concentrated in small areas and offline communication makes it convenient to pass on their ideas. Another distinguishing feature in adoption is the external surroundings and their elements, as proved in Hypothesis 12. People prefer to use a technology if someone is there to help them in case of any usage dilemma, which is a facilitating factor for urban people and a detrimental factor for rural ones.

For over a decade, the preference of online customers has slowly shifted away from e-commerce towards $\mathrm{m}$-commerce. This may be attributed to the technological infrastructure and mobile data facilities provided to online purchasers, through a wireless device which can be accessed anywhere and anytime. A legacy of studies exist that have keenly focused on determining the antecedents of intention to adopt mobile commerce. For this purpose, researchers have used the TAM or UTAUT model or their combination, along with their extensions to justify their problem's objective. This study combines both the models to choose the determinants of mobile acceptance 
intention. A structural framework is proposed with the determinants as exogenous latent variables and behavioral intention as an endogenous variable. For this purpose, data collected from 200 respondents in Delhi NCR was used to validate the proposed model using the PLS-SEM approach. The results of PLS-SEM accepted the hypotheses underlying the model and also validated the moderating role played by a respondent's locality over the m-commerce adoption intention. However, since the study was conducted in a metropolitan city of India, the results may differ in other cities, and thus may not be generalized for a developing economy. Moreover, further studies can be conducted by considering other combination of determinants and extending the model to incorporate the loyalty measures.

\section{ACKNOWLEDGEMENT}

This research work was supported by the grants provided by the Indian Council of Social Science Research, Delhi, India (File No.: 02/76/2017-18/RP/Major).

\section{REFERENCES}

[1] T. He, Y. Wang, and W. Liu, "Empirical Research on Mobile Commerce Use: an Integrated Theory Model," Advances in Information Sciences and Service Sciences, vol. 4, pp. 23-32, 2012. [Online]. doi: 10.4156/aiss.

[2] A. G. Aggarwal and Aakash, "Multi-criteria-based prioritisation of B2C e-commerce website," International Journal of Society Systems Science, vol. 10, pp. 201-222, 2018. [Online]. doi: https://doi.org/10.1504/IJSSS.2018.093940.

[3] riversand. (2018, May). [Online]. Available: https://www.riversand.com/blog/mobilecommerce-india-to-jump-in-2017.

[4] Statista. (2018, March). [Online]. Available: www.statista.com.

[5] cio.in. (2018, May). Available: http://www.cio.in/feature/2018-era-mobile-commerce-ande-payments.

[6] exchange4media.com. (2018, May). [Online]. Available: https://www.exchange4media.com/ Digital/Smartphones-are-catalyst-to-m-commerce-growth-in-India_46464.html. 
[7] S. Ahmad and W. M. A. B. W. Afthanorhan, "The importance-performance matrix analysis in partial least square structural equation modeling (PLS-SEM) with smartpls 2.0 M3," International Journal of Mathematics Research, vol. 3 (1), pp. 1-14, 2014. [Online]. Available: https://pdfs. semanticscholar.org/4f39/b186b485d102ac46f86b5275040e51144d4b.pdf.

[8] J. Henseler, C. M. Ringle, and M. Sarstedt, "A new criterion for assessing discriminant validity in variance-based structural equation modeling," Journal of the academy of marketing science, vol. 43 (1), pp. 115-135, 2015. [Online]. doi: 10.1007/s11747-014-0403-8.

[9] F. D. Davis, "A technology acceptance model for empirically testing new end-user information systems: Theory and results," Massachusetts Institute of Technology, 1985. [Online]. Available: http://hdl.handle.net/1721.1/15192.

[10] S. H. Kim, "A study on adoption factors of Korean smartphone users: A focus on TAM (Technology Acceptance Model) and UTAUT (Unified Theory of Acceptance and Use of Technology)," Advanced Science and Technology Letters, vol. 57 (1), pp. 27-30, 2014. [Online]. doi: http://dx.doi.org/10.14257/astl.2014.57.07.

[11] M. Groß, "Exploring the acceptance of technology for mobile shopping: an empirical investigation among Smartphone users," The International Review of Retail, Distribution and Consumer Research, vol. 25 (3), pp. 215-235, 2015. [Online]. doi: https://doi.org/10.1080/0959 3969.2014.988280.

[12] V. Venkatesh and F. D. Davis, "A theoretical extension of the technology acceptance model: Four longitudinal field studies," Management science, vol. 46 (2), pp. 186-204, 2000. [Online]. doi: https://doi.org/10.1287/mnsc.46.2.186.11926.

[13] J. Khalilzadeh, A. B. Ozturk, and A. Bilgihan, "Security-related factors in extended UTAUT model for NFC based mobile payment in the restaurant industry," Computers in Human Behavior, vol. 70 (May), pp. 460-474, 2017. [Online]. doi: https://doi.org/10.1016/j.chb.2017.01.001.

[14] D. C.-F. Lai, I. K.-W. Lai, and E. Jordan, "An extended UTAUT model for the study of negative user adoption behaviours of mobile commerce," in Proceedings of the Ninth International Conference on Electronic Business, 2009. [Online]. Available: https://pdfs.semanticscholar. org/361f/b677bf07fd458c09bfc71631b50b838c14c7.pdf.

[15] J. C. Sánchez-Prieto, S. Olmos-Migueláñez, and F. J. García-Peñalvo, "MLearning and pre-service teachers: An assessment of the behavioral intention using an expanded TAM model," Computers in Human Behavior, vol. 72 (July), pp. 644-654, 2017. [Online]. doi: https://doi. org/10.1016/j.chb.2016.09.061. 


\section{Abhishek Tandon, Himanshu Sharma, Anu G. Aggarwal}

[16] R. de Sena Abrahão, S. N. Moriguchi, and D. F. Andrade, "Intention of adoption of mobile payment: An analysis in the light of the Unified Theory of Acceptance and Use of Technology (UTAUT)," RAl Revista de Administração e Inovação, vol. 13 (3), pp. 221-230, 2016. [Online]. doi: https://doi.org/10.1016/j.rai.2016.06.003.

[17] Q. Min, S. Ji, and G. Qu, "Mobile commerce user acceptance study in China: a revised UTAUT model," Tsinghua Science \& Technology, vol. 13 (3), pp. 257-264, 2008. [Online]. doi: 10.1016/ S1007-0214(08)70042-7.

[18] V. Venkatesh, M. G. Morris, G. B. Davis, and F. D. Davis, "User acceptance of information technology: Toward a unified view," MIS quarterly, vol. 27 (September), pp. 425-478, 2003. [Online]. doi: $10.2307 / 30036540$.

[19] V. Venkatesh, J. Y. Thong, and X. Xu, "Consumer acceptance and use of information technology: extending the unified theory of acceptance and use of technology," MIS quarterly, vol.36 (1), pp. 157-178, 2012. [Online]. Available: https://papers.ssrn.com/sol3/papers. cfm?abstract_id=2002388.

[20] D.-H. Shin, "Towards an understanding of the consumer acceptance of mobile wallet," Computers in Human Behavior, vol. 25 (November), pp. 1343-1354, 2009. [Online]. doi: https:// doi.org/10.1016/j.chb.2009.06.001.

[21] D.-H. Shin, "Modeling the interaction of users and mobile payment system: Conceptual framework," International Journal of Human-Computer Interaction, vol. 26 (10), pp. 917-940, 2010. [Online]. doi: 10.1080/10447318.2010.502098.

[22] T. Zhou, "Understanding mobile Internet continuance usage from the perspectives of UTAUT and flow," Information Development, vol. 27 (3), pp. 207-218, 2011. [Online]. doi: https://doi. org/10.1177/0266666911414596.

[23] C.-S. Yu, "Factors affecting individuals to adopt mobile banking: Empirical evidence from the UTAUT model," Journal of Electronic Commerce Research, vol. 13 (2), p. 104-121, 2012. [Online]. doi: http://www.jecr.org/node/48.

[24] R. Thakur, "Customer adoption of mobile payment services by professionals across two cities in India: An empirical study using modified technology acceptance model," Business Perspectives and Research, vol. 1 (2), pp. 17-30, 2013. [Online]. doi: https://doi. org/10.1177/2278533720130203. 
[25] E. L. Slade, Y. K. Dwivedi, N. C. Piercy, and M. D. Williams, "Modeling consumers' adoption intentions of remote mobile payments in the United Kingdom: extending UTAUT with innovativeness, risk, and trust," Psychology \& Marketing, vol. 32 (8), pp. 860-873, 2015. [Online]. doi: https://doi.org/10.1002/mar.20823.

[26] J. Khalilzadeh, A. B. Ozturk, and A. Bilgihan, "Security-related factors in extended UTAUT model for NFC based mobile payment in the restaurant industry," Computers in Human Behavior, vol. 70 (May), pp. 460-474, 2017. [Online]. doi: https://doi.org/10.1016/j.chb.2017.01.001.

[27] A. A. Shaikh, R. Glavee-Geo, and H. Karjaluoto, "How relevant are risk perceptions, effort, and performance expectancy in mobile banking adoption?, International Journal of E-Business Research (IJEBR), vol. 14 (2), pp. 39-60, 2018. [Online]. doi: 10.4018/IJEBR.2018040103.

[28] F. D. Davis, R. P. Bagozzi, and P. R. Warshaw, "Extrinsic and intrinsic motivation to use computers in the workplace," Journal of applied social psychology, vol. 22 (14), pp. 1111-1132, 1992. [Online]. doi: https://doi.org/10.1111/j.1559-1816.1992.tb00945.x.

[29] T. D. Nguyen, T. M. Nguyen, and T. H. Cao, "The relationship between IT adoption, IS success and project success," in International Conference on Advances in Computing, Communications and Informatics (ICACCI), Jaipur, India, 2016, pp. 1192-1198. [Online]. doi: 10.1109/ ICACCI.2016.7732207.

[30] R. Rahayu and J. Day, "Determinant factors of e-commerce adoption by SMEs in developing country: evidence from Indonesia," Procedia-Social and Behavioral Sciences, vol. 195 (July), pp. 142-150, 2015. [Online]. doi: https://doi.org/10.1016/j.sbspro.2015.06.423.

[31] C. Morosan and A. DeFranco, "It's about time: Revisiting UTAUT2 to examine consumers' intentions to use NFC mobile payments in hotels," International Journal of Hospitality Management, vol. 53 (February), pp. 17-29, 2016. [Online]. doi: https://doi.org/10.1016/j.ijhm.2015.11.003.

[32] J. Weisberg, D. Te'eni, and L. Arman, "Past purchase and intention to purchase in e-commerce: The mediation of social presence and trust," Internet research, vol. 21 (1), pp. 82-96, 2011. [Online]. doi: https://doi.org/10.1108/10662241111104893.

[33] M.-I. R. M. Jaradat and K. M. Faqih, "Investigating the moderating effects of gender and self-efficacy in the context of mobile payment adoption: A developing country perspective," International Journal of Business and Management, vol. 9 (11), p. 147, 2014. [Online]. doi: http://dx.doi.org/10.5539/ijbm.v9n11p147. 
[34] S. Rezaei, "Segmenting consumer decision-making styles (CDMS) toward marketing practice: A partial least squares (PLS) path modeling approach," Journal of Retailing and Consumer Services, vol. 22 (January), pp. 1-15, 2015. [Online]. doi: https://doi.org/10.1016/j. jretconser.2014.09.001.

[35] K. K.-K. Wong, "Partial least squares structural equation modeling (PLS-SEM) techniques using SmartPLS," Marketing Bulletin, vol. 24 (January), pp. 1-32, 2013. [Online]. Available: http://marketing-bulletin.massey.ac.nz/V24/MB_V24_T1_Wong.pdf.

[36] J. Gaskin, "Multigroup Moderation in AMOS," Gaskination's Statistics, 2011. [Online]. Available: http://youtube. com/Gaskination

\section{APPENDEX}

\begin{tabular}{cl}
\hline Item & Statement \\
\hline PEOU1 & I think learning to use MC is easy \\
\hline PEOU2 & I think finding what I want via MC is easy \\
\hline PEOU3 & I think using MC is easy \\
\hline PU1 & Using MC would improve my performance in online transactions \\
\hline PU2 & Using MC would make it easier for me to engage in online transactions \\
\hline PU3 & I think using MC is very useful for me to engage in online transactions \\
\hline PR1 & I think using MC in monetary transactions has potential risk \\
\hline PR2 & I think using MC in product purchases has potential risk \\
\hline PR3 & I think using MC puts my privacy at risk \\
\hline PC1 & Mobile apps are reasonably priced \\
\hline PC2 & Mobile apps are a good value for the money \\
\hline PC3 & At the current price, mobile apps provide a good value \\
\hline SI1 & My peers, friends, and family thought that I should use MC \\
\hline SI2 & People I knew thought that using MC is a good idea \\
\hline SI3 & People I knew influenced me to try out MC \\
\hline FC1 & Mobile apps are compatible with other technologies I use \\
\hline FC2 & I can get help from others when I have difficulties using mobile apps \\
\hline FC3 & I feel comfortable using mobile apps \\
\hline IA1 & Assuming I had access to MC, I intend to use it \\
\hline IA2 & Given that I had access to MC, I predict that I would use it \\
\hline
\end{tabular}

